\title{
LINGUISTIC COMPETENCE AND LANGUAGE CODE OF THE NEW TURKISH LANGUAGE
}

\author{
(c) Rupiya I. Bachieva, Marin Sh. Ramazanova, Rashiya I. Isaeva
}

\author{
Rostov State University of Economics, Rostov-on-Don; Dagestan State Medical University; \\ Dagestan State University of National Economy, Makhachkala, Republic of Dagestan, \\ Russian Federation \\ science-almanac@mail.ru
}

Turkish was spoken in vast territories stretching from the modern territory of Mongolia to the northern coast of the Black Sea, the Balkans, Eastern Europe, Anatolia, Iraq and the vast territory of northern Africa. Turkish was in contact with various languages that are not identical in origin. For this reason, there was mutual influence and borrowing between these languages and the Turkish language, which are the inevitable consequence of such a long contact. The population of areas where the language was long-spread, as well as of nearby territories which were under its influence in various historical periods, gradually formed and transmitted various dialects and accents from generation to generation. The entire history of the existence of the Turkish people language can be represented by three main groups: Old Turkish (from the $7^{\text {th }}$ to the $13^{\text {th }}$ centuries), Middle Turkish (from the $13^{\text {th }}$ to the $20^{\text {th }}$ centuries) and New Turkish, starting from the $20^{\text {th }}$ century. The fact that the New Turkish language has its own phonetic, morphological and syntactic structures and a rich vocabulary makes it possible to consider it as a cultural and social phenomenon through the concept of the national connection of the Turkish people and linguistic competence as a system of linguistic knowledge possessed by native speakers of the Turkish language.

Key words: Turkish language, language competence, language code, communication, non-verbal communication

\section{[Р.И. Бачиева, М.Ш. Рамазанова, Р.И. Исаева Лингвистическая компетенция и языковой код нового турецкого языка]}

Турецкий язык был распространен на обширных территориях, простирающихся от современной территории Монголии до северного побережья Черного моря, Балкан, Восточной Европы, Анатолии, Ирака и обширной территории северной Африки. Турецкий язык контактировал с различными языками, которые не идентичны его по происхождению. По этой причине между этими языками и турецким языком было взаимное влияние и заимствования, представляющие собой неизбежное последствие столь длительного контакта. Население районов, где язык был длительно распространен, а также близлежащих территорий, находящихся под его воздействием в различные исторические периоды, постепенно фрормировало и передавало из поколения в поколение различные диалекты и акценты. Всю историю существования языка турецкого народа можно представить тремя основными группами: старотурецкий (с VII по XIII века), среднетурецкий (с XIII по XX век) и новый турецкий, начиная с XX века. Тот факт, что новый турецкий язык имеет свою фонетическую, морфологическую и синтаксическую структуры и обладает богатым словарным запасом дает возможность рассмотреть его как культурный и социальный френомен через понятие национальной связи турецкого народа и лингвистической компетенции как системы языковых знаний, которыми обладают носители турецкого языка.

Ключевые слова: турецкий язык, языковая компетентность, языковой код, коммуникация, невербальное общение.

Rupiya I. Bachieva - Ph.D. in Philology, Associate Professor, Rostov State University of Economics, Rostov-onDon, Russian Federation.

Marin Sh. Ramazanova - Ph.D. in Philology, Associate Professor, Dagestan State Medical University, Makhachkala, Republic of Dagestan, Russian Federation.

Rashiya I. Isaeva - Assistant Professor, Dagestan State University of National Economy, Makhachkala, Republic of Dagestan, Russian Federation.

Бачиева Рупия Изитдиновна - кандидат фрилологических наук, доцент, Ростовский государственный экономический университет, г. Ростов-на-Дону, Российская Федерация. 
Рамазанова Марин Шарапудиновна - кандидат филологических наук, доцент, Дагестанский государственный медицинский университет, г. Махачкала, республика Дагестан, Российская Федерация. Исаева Рашия Изитдиновна - старший преподаватель, Дагестанский государственный университет народного хозяйства, г. Махачкала, республика Дагестан, Российская Федерация.

The ancient Turkish language had been a single language of the Turkish people for more than five thousand years from east to west, from north to south, with a small difference in dialect. Due to certain historical conditions and as a result of contact with foreign cultures and peoples, especially during the Ottoman Empire, Arabic and Persian words occupied a significant part in the Turkish language. Five years after the proclamation of Turkey, in 1928, the Arabic alphabet used by the Turks was replaced by Latin, that significantly freed the Turkish language from borrowed words, and became the beginning of the history of the New Turkish language. The replacement words were taken from the Old Turkish language (from the $7^{\text {th }}$ to the $13^{\text {th }}$ centuries), partially preserved among the rural population, (kaba Türkçe is the rough Turkish language), Old Turkic and other Turkic languages or in some cases simply invented on the spot as in the case of okul (school). Changes in the language were irreversible, progressive and extensive. The national language, like... "communication process helps to find psychological rapprochement through verbal or non-verbal communication, reflecting the axiological space of different cultures. Communication is presented not only as a condition of human existence, but also as a means of shaping and developing social experience and belonging to a particular culture [3, p. 3]. The $20^{\text {th }}$ century for the Turkish nation is a new country, a new language, a new social experience. Most people in Turkey have become Turkized through education, work, service, and intermarriage [8].

Although Turkish words seem to be long and complex, knowledge of methods of word formation and rules for each of the parts of the sentences show that Turkish is an ordinary and logical language. It occupies an extremely important place in the cultural life of the nation.

As a result of the efforts of the Turkish Language Research Society (Türk Dil Kurumu, TDK) [16], founded by the first President of Turkey M. Atatürk on July 12, 1932 to conduct linguistic research and promote the natural development of the language, the modern Turkish language has become a literary and cultural language, developing naturally and free from foreign influences.

Turks are one of the few nations in the world that have their own script, their own alphabet, although there is an unproven statement that this writing system, which is today called the Orkun or Yenisei alphabet, has borrowings from the languages of other peoples. The national Turkish script, also called the Turkish alphabet Kök, is interesting because it shows all the sounds in Turkish. Education throughout the whole history of Turkey has been given as much importance as training in horseback riding and camel riding, sword use, arrow shooting, etc. [10]. "Currently, the national Turkish language is a synthesis of the Turkish folk language, the ancient Turkic language and the Asian Turkic languages, as well as borrowing from the vocabulary of other languages" [14, pp. 65-70]. Twenty-one consonants and eight vowel letters represent the alphabet of the modern Turkish language. Unlike fusional languages (or flexional ones using inflection for word formation and inflection), which allow modifications of one or both phonetics or writing one or more morphemes in a word, agglutinative Turkish includes agglutination, which leads to significant variations in pronunciation in different contexts. Thus, words can contain different morphemes to determine their meaning, but each morpheme (including parts of the word) remains unchanged. Another feature of the Turkish language is the lack of gender of nouns (masculine, feminine, neuter). In the linguistic typology of the Turkish language, there is the so-called standard order subject-object-verb SOV, but like all Turkic languages, Turkish has flexibility, the order can be changed to object-verb-subject (OVS), verbsubject-object (VSO), etc. 
After the liberation of Turkey by the Treaty of Lausanne (1922) and the recognition of the borders of Turkey (1923), the secular Turkish Republic was proclaimed.

In Turkish, the name of the country is Türkiye. Today's Republic of Turkey, also known as Turkey, is a transcontinental country that includes Anatolia in Western Asia and Eastern Thrace in southern Europe. Thus, it can be said that Turkey is a country of both East and West, which is washed by the waters of four seas: Mediterranean, Black, Aegean, Marmara and borders with eight countries: Bulgaria, Greece, Georgia, exclave of the Republic of Azerbaijan Nakhchivan Autonomous Republic, Iran, Armenia, Syria, Iraq. The population of Turkey currently is $84,839,7$ million people: $49.9 \%$ of women and $50.1 \%$ of men. Turkey's capital Istanbul (formerly Constantinople) is the most populous city and the eighth largest city in the world with a population of 14,808.1 million people in 2021 [16].

When defining the youth "from post-adolescence to adulthood," as the main engine for the growth of culture, which constitutes the "technologically literate" [5, pp. 145-147] part of the population, we can say that the Turkish population is quite young: almost $27 \%$ are aged from 0 to 14 years, and $67 \%$ from 15 to 64 years, and only about $6 \%$ of the population of Turkey is over 64 years old. The average age of the population is 30.9 years [11].

Strict etiquette regulates intergenerational and heterosexual relationships. Elderly people who are not relatives or friends are officially addressed with the title "bey" (master), and women with the title "hanim" (lady) [8].

Every new generation, as O. Packez notes in the article "One Generation, One Future," is the future of a country that represents the future position and power of its nation. This is the largest investment in the country's industrial, economic, legal and military industries. "The audience we are talking about is today's young people learning to work with the computer, tomorrow's officers, politicians, economists, engineers, etc. New generations monitor the progress of problems until their turn comes, identify the problem and begin to develop methods of its solving. The individual differences of the generation that is growing today are higher than those of previous generations, "manifesting themselves in "their ability, ideas, ethnic origin, religious views, and even ways of problem solving." However, the author further notes, "their common values are the flag, national consciousness, constitutional loyalty, civic awareness and many spiritual values." The weakening of one of these "common values leads to the fact that the generation loses contact with the previous one," which can lead to a split in the nation and a prolonged interethnic conflict [13]. No matter what culture and/or religion people belong to, if the language of the nation disappears, it is impossible to talk about this society. Language is the most important factor that makes society a nation. Language is "not only a means of conveying feelings and thoughts to people, but also an essential cultural value that saves human communities from the mass and turns them into a community with a "union of feelings and thoughts," which is a "nation"." In addition, the language is the basis of a culture, as well as its carrier... If you destroy the language, there will be no such thing as a national spirit and culture. For this reason, it is important to protect the language and take measures to protect it [15].

The term linguistic competence as grammatical or language competence belongs to the knowledge of grammar which allows the speaker to use and understand the first (native) language. The national structure of Turkey is represented by $75 \%$ of the Turks, $18 \%$ of the Kurds and $17 \%$ of other ethnic groups. Respectively the Turkish and Kurdish languages are spoken by most of inhabitants whereas groups of minorities (the Arabs, the Laz people, the Georgians, the Armenians, the Jewish people etc.) express double identity, and in the family or among themselves, as a rule, speak "their" languages [11].

One of the components of culture is "subjective culture, which involves general knowledge, beliefs, collective memories of identity, relationships, values and practices used by members of the group as a common coordinate system for thinking and attitude to the world [4, pp. 50-57]. 
There are no restrictions on ethnicity or ethnic identity cards in the Republic of Turkey. In recent years, ethnic minorities, different from linguistic, ethnic and cultural characteristics of the Turks living in Turkey (the Kurds, the Georgians, the Circassians, the Laz people, etc.) have published newspapers, magazines and books in their own language. Children of ethnic minorities living in Turkey study their native languages at school: Armenian, Georgian, Hebrew, Kurdish, etc.

It should be noted that language competence is not considered in the article as an evaluation term, but rather as referring to linguistic knowledge that allows a person to compare sounds and meanings. N. Chomsky in "Aspects of Syntax Theory" writes: ... "we see a fundamental difference between competence (knowledge of the speaker of his language) and performance (actual use of the language in specific situations). According to the theory of the scientist, linguistic competence functions "properly" only in idealized conditions, which theoretically will eliminate any obstacles associated with memory, distraction, emotions and other factors. Such factors can also lead grammatically correct native speakers to grammatical errors, which is closely related to the concept of grammar, which states that all native speakers unknowingly understand the "rules" governing the language [7, p. 73].

If people with complex communicative needs need to develop communicative competence, they should develop sufficient knowledge, judgment and language code skills of the language (languages) spoken and written in the family of the man and wider social community, including perceptual skills and many other expressive skills in these languages if possible. In addition, they should also study the language code of additional and active communication systems used by them, including representative aspects of communication symbols [12, pp. 107-146]. The code establishes a relationship between signs, the code determines the structure of the language, that is, it is a kind of systematic regulatory element, includes: "a certain bilateral set of encryption and decryption message rules" [1, p. 111].

Non-language systems are semantic systems that include symbol sets to convey concepts, but do not have their own syntax or morphology. Between the language code through which people receive input data there is the spoken language of their families and the wider social code of the community, through which they express the content of a multimodal expression, which may include the use of some speech approximations, the use of gestures or signs, the use of auxiliary symbols of communication.

For example, non-verbal behavior in the process of communication "plays an important role, it helps to share emotions, agreements and disagreements, it helps to tell about intentions along with the verbal language." Even a perfect command of the verbal language of another people without the skills of non-verbal behavior associated with this language, despite the fluency of speech, can lead to "misunderstanding and ambiguity in communication and even intercultural conflict" [2, p. 86]. So, for example, in Turkey, hands in your pocket mean disrespect; sitting with crossed legs means an insult; a hand gesture in English-speaking countries meaning "everything is good" or "agreement" - OK, which is performed by connecting the thumb and the index finger and holding other fingers straight away from the palm of the hand, in Turkey refers to bad gestures accusing homosexuality; a kiss on the cheek, allowed in other countries when meeting with friends and acquaintances, in Turkey is possible only with well-known people and close relatives etc.

In addition, people with complex communication needs usually have limited access to models of effective communication through communication itself [6, pp. 446-457]. G. Estrella, notes that an experienced communicator through communication, emphasizes the importance of a coordinated intervention for the development of language skills underlying "communicative competence" [9, p. 45].

Since, based on the location, and the division of the Republic and the capital of Turkey into the European and Asian parts, Turkey can be described as a kind of a "bridge" between 
Asia and Europe. Turkish is an important language, as well as a gender-free language with predictable grammar using various suffixes, which makes it interesting and fascinating to consider communicative competence.

\section{Лumepamypa}

1. Петрова Ю.А. Репрезентация ценностей молодежной субкультуры в ценностносмысловом пространстве языка. Дис. канд. фрилос. н. 2012.

2. Петрова Ю.А. Язык как средство отражения субкультуры молодежи. Ростов-наДону: Издательско-полиграфический комплекс РГЭУ (РИНХ), 2019.

3. Петрова Ю.А. Язык как модель ценностного пространства культуры. Ростов-наДону: Издательско-полиграфический комплекс РГЭУ (РИНХ), 2019.

4. Петрова Ю.А. Многокультурность и межкультурность, культура и язык в XXI веке // Гуманитарные и социальные науки. 2019. № 4.

5. Хатуев 3. 3., Петрова Ю.А. Молодежь как основной потребитель в медиа секторе в XXI веке // Гуманитарные и социально-экономические науки. 2020. № 2 (111).

6. Ballin, L., Balandin, S., Stancliffe, R. J., \& Togher, L. Speech-language pathologists' views on mentoring by people who use speech generating devices. International Journal of Speech-Language Pathology. 2011. 13 (5). P. 446-457.

7. Chomsky N. Aspects of the Theory of Syntax, MIT Press. P. 73. 1969, P. 251.

8. Countries and their cultures. Culture of Turkey. URL: https://www.everyculture.com.

9. Estrella G. Confessions of a blabber finger. In M. Fried-Oken \& H. Bersani (Eds.), Speaking up and spelling it out, Baltimore. 2000. P. 31-45.

10. Gömeç S. Y. Bir Kültür Unsuru Olarak Türk Dili ve Önemi, Ankara, 2008. URL: https://www.altayli.net.

11. Güder, D. Elderly Statistics, 2020 Technical Info. URL: https://data.tuik.gov.tr/Bulten/Index?p=Elderly-Statistics-2020-37227.

12. Mineo Mollica B. Representational competence. In J.C. Light, D.R. Beukelman, \& J. Reichle (Eds.), Communicative competence for individuals who use AAC: From research to effective practice, Baltimore. 2003. P. 107-146.

13. Pekgöz Ö.F. Bir Kuşak Bir Gelecek, Anka Enstitüsü, 2021. URL: http://ankaenstitusu.com.

14. Petrova Yu., Kuleshova K. Cultural and historical evolution of the Turkish language under the influence and borrowing of European languages. Научный альманах стран Причерноморья. 2020. 1 (21). C. 65-70.

15. Serkan A. Y. Türk Dilinin önemi nedir? 2013. URL: https://kisa-ozet.org.

16. Türk Dil Kurumu'nun Kuruluşu, 2017. URL: http://ankaenstitusu.com.

\section{References}

1. Petrova Iu.A. Reprezentatsiia tsennostei molodezhnoi subkultury $v$ tsennostno-smyslovom prostranstve iazyka. Dis. kand. filos. $\mathrm{n}$. [Representation of values of the youth subculture in the axiological space of the language. Thesis of the candidate of philosophical sciences]. 2012 (in Russian).

2. Petrova lu.A. lazyk kak sredstvo otrazheniia subkultury molodezhi. [Language as a means of reflecting the subculture of youth]. Rostov-na-Donu: Izdatelsko-poligraficheskii kompleks RGEU (RINKh). 2019 (in Russian).

3. Petrova lu.A. lazyk kak model tsennostnogo prostranstva kultury. [Language as a model of the value space of culture.]. Rostov-na-Donu: Izdatelsko-poligraficheskii kompleks RGEU (RINKh). 2019 (in Russian). 
4. Petrova Iu.A. Mnogokulturnost i mezhkulturnost, kultura i iazyk v XXI veke. [Multiculturalism and interculturalism, culture and language in the $21^{\text {st }}$ century]. Gumanitarnye i sotsialnye nauki. 2019. No. 4 (in Russian).

5. Khatuev Z.Z., Petrova Iu.A. Molodezh kak osnovnoi potrebitel v media sektore v XXI veke. [Youth as the main consumer in the media sector in the $21^{\text {st }}$ century.]. Gumanitarnye i sotsialno-ekonomicheskie nauki. 2020. No. 2 (111) (in Russian).

6. Ballin, L., Balandin, S., Stancliffe, R.J. \& Togher, L. Speech-language pathologists' views on mentoring by people who use speech generating devices. International Journal of Speech-Language Pathology. 2011. 13 (5). pp. 446-457.

7. Chomsky N. Aspects of the Theory of Syntax, MIT Press. 1969. 251 p.

8. Countries and their cultures. Culture of Turkey. Available at: https://www.everyculture.com.

9. Estrella G. Confessions of a blabber finger. In M. Fried-Oken \& H. Bersani (Eds.), Speaking up and spelling it out, Baltimore. 2000. pp. 31-45.

10. Gömeç S.Y. Bir Kültür Unsuru Olarak Türk Dili ve Önemi, Ankara, 2008. Available at: https://www.altayli.net.

11. Güder D. Elderly Statistics, 2020 Technical Info. Available at: https://data.tuik.gov.tr/Bulten/Index?p=Elderly-Statistics-2020-37227.

12. Mineo Mollica B. Representational competence. In J.C. Light, D.R. Beukelman, \& J. Reichle (Eds.), Communicative competence for individuals who use AAC: From research to effective practice, Baltimore. 2003. pp. 107-146.

13. Pekgöz Ö.F. Bir Kuşak Bir Gelecek, Anka Enstitüsü, 2021. Available at: http://ankaenstitusu.com.

14. Petrova Yu., Kuleshova K. Cultural and historical evolution of the Turkish language under the influence and borrowing of European languages. Science Almanac of Black Sea Region Countries. 2020. 1 (21). pp. 65-70.

15. Serkan A. Y. Türk Dilinin önemi nedir? 2013. Available at: https://kisa-ozet.org.

16. Türk Dil Kurumu'nun Kuruluşu, 2017. Available at: http://ankaenstitusu.com. 